\title{
Finding Meaning in Life: Challenges Confronting Young People in Selected Novels by John McGahern
}

\author{
Prof. Asad Al-Ghalith, \\ Dr. Mohsen Hashem, \\ University of Tabuk, Tabuk, Saudi Arabia
}

doi: 10.19044/esj.2016.v12n2p120 URL:http://dx.doi.org/10.19044/esj.2016.v12n2p120

\begin{abstract}
This article aims at exploring the challenges that face the central characters in selected novels by the Irish writer John McGahern. The major characters in John McGahern's fiction are confronted by serious challenges and obstacles. This can be noted in many novels by McGahern such as The Dark and The Leave-taking . For instance, In The Dark, young Mahoney is dominated by his father who hinders his son's growth as a young man. Likewise, The Leave-taking is a book of challenges facing the youth. We are here told that Moran is a teacher who is about to lose his favorite job as a teacher simply because he ignores the church rituals and decides to marry a foreign divorcee in a registry office. Remarkably, each of these young people is confronted with a difficulty that hampers his present life and impedes his future aspirations. However, McGahern tells us that his characters struggle continuously to achieve some sort of settlement. Each one tries to set a plan for living that helps him to lead a happy life despite the heavy burden of challenges that he faces. By the end of each novel, we are astonished to see that each of the characters has admirably affirmed some meaning in his life. There is a universal lesson to be learned by youth everywhere from the examples offered by our author in these novels.
\end{abstract}

Keywords: McGahern, The Dark, The Leave-taking, challenges, youth, young people, main characters

The major characters in John McGahern's fiction are confronted by serious challenges and obstacles. This can be noted in many novels by McGahern such as The Dark and The Leave-taking. For instance, In The Dark, young Mahoney is dominated by his father who hinders his son's growth as a young man. Likewise, The Leave-taking is a book of challenges facing the youth. We are here told that Moran is a teacher who is about to lose his favorite job as a teacher simply because he ignores the church rituals 
and decides to marry a foreign divorcee in a registry office. Remarkably, each of these young people is confronted with a difficulty that hampers his present life and impedes his future aspirations.

However, McGahern tells us that his characters struggle continuously to achieve some sort of settlement. Each one tries to set a plan for living that helps him to lead a happy life despite the heavy burden of challenges that he faces. By the end of each novel, we are astonished to see that each of the characters has admirably affirmed some meaning in his life. There is a universal lesson to be learned by youth everywhere from the examples offered by our author in these novels.

In The Dark, we are told that the protagonist is facing conditions of mental and physical brutality from his domineering father. Here, the father is the main cause and major tool of cruelty and punishment. The father does his best to dominate the character of his son, and this is a real challenge faced by the poor young man. As McGahern tells us in the book, the young man moans in vain, suffering from a highly cruel and dictatorial father:

He'd never imagined horror such as this, waiting naked for the leather to come down on his flesh, would it ever come, it was impossible and yet nothing could be much worse than this waiting. (9)

As we see throughout the novel, young Mahoney tries hard to free himself from this unbearable atmosphere. He takes three serious steps. Firstly, he begins to work hard and hard in school. Secondly, he plans to be a priest whom people respect and esteem. Thirdly, he works day and night till he successfully gets a scholarship to study at the University of Galway and get liberated from this present situation. However, the father does not like this. Each time, he does his best to stand against his son's success, simply because he likes to make the son a similar copy of him, working in the farm and leading the same miserable life. In the words of the domineering father, McGahern writes in the novel,

He'll be like me I suppose. He'll wear out his bones on the few acres round this house and be buried at the end of the road.

However, Young Mahoney resists this dominance and swears that he will never be what his father wants him to be. In other words, the young man completely rejects the idea that he will be a follower of his father who wants him to live and die in the farm like him. In the words of Kennedy,

Young Mahoney begins to work out his life through a tentative exploration of the possibilities of freedom and liberation from his father's control and the hard work of the farm. (120)

McGahern tells us in the novel that Young Mahoney sees that he will not be his father. Alternately, he wishes to be 
a priest if he got the chance, and there were dreams of wooden pulpits and silence of churches, walking between yew and laurel paths in prayer, an old house with ivy and a garden, orchards behind. He'd walk that way through life towards the unnamed heaven of joy, not his father's path. (25)

Responding to Young Mahoney's aims and dreams of success, the father adopts the attitude of indifference and lack of interest rather than support and encouragement. He disinterestedly tells his son:

It's your decision. I won't have you blaming me for the rest of your life that the one chance you did get that I stood in your way. Do what you want to do. (26)

However, the reaction of the young man towards his father is worth noting; he knows well that his domineering father wants him to stay away from school and work in the fields forever. He decidedly says, "'I'll go," he said and he knew he was defying Mahoney, some way he'd be made pay for it," McGahern writes in the novel (26).

The young man tries to calm his father down by pretending to do some work in the farm. He sometimes succeeds and other times faces failure and disappointment. However, he is determined to succeed and excel in his studies and achieve his academic goals.

Another way out that Young Mahoney resorts to is to become a priest. According to him, the priest is always respected by people and is often feared by them. He himself experiences this kind of fear from Father Gerald. "FATHER GERALD CAME EVERY YEAR," he states adding, HE WAS A COUSIN AND HIS coming was a kind of watch. Mahoney hated it, but because of his fear of a priest's power he made sure to give the appearance of a welcome. (24)

However, Young Mahoney's fascination with the priesthood ends after his meeting with his cousin the priest, Father Gerald who gives a bad example of priesthood and this of course frustrates him. Again his escape is blocked. The priest's life does not appeal to him, and he comes to decide that the priesthood is not for him. He then decides to give up the idea of having such a job. He disappointedly says to himself, "You couldn't be a priest, never now, that was all," adding,

You'd never raise anointed hands. You'd drift into the World....

Your life seemed set, without knowing why, it was fixed, you had no choice. You were a drifter, you'd drift a whole life long after pleasure, but at the end there'd be the reckoning. If you could be a priest you'd be able to enter that choking moment without fear, you'd have already died to longing, you'd have already abandoned the world for that reality, there'd be no 
confusion. But the night and room and your father and even the hedge around the orchard at home were all confusion...(77)

After all these continuous experiences of disappointment and frustration, Young Mahoney discovers that excelling in education will probably be the only way out of his dilemma; it will be his ship of hope out of his present life towards success, freedom, and distinctiveness. He himself states that he is heading out into an uncertain life, sacrificing

the certainty of a life based on death; for what you didn't know, windblown excitements and imaginings that in the humdrum of their actuality might soon get stripped of their sensual marvel.

But no, you'd set your face another direction. (127)

The hard blows directed to him by fate have made him stronger and stronger. He encourages himself saying:

Come on, try it, hit your father, the pup is stronger than the dog.

Come on, my pup, and try it." You hadn't the strength even if you'd wanted. The whole kitchen and world was sick and despairing. Hatred had drained everything empty. (37)

It is worth noting that Young Mahoney begins to find himself, overcome the miserable situation he is faced with, and more importantly he starts to manage dealing with the father's rough treatment. He finally gets the scholarship he has long sought to study outside Ireland. In this way, his begins to succeeed and have a better life, a life of his own away from the domination of the cruel father.

Remarkably, Young Mahoney is no longer Young Mahoney, but Mr. Mahoney, an independent individual who can make his decision and plan for his own life freely and autonomously. He gladly speaks to himself saying: ...you could laugh purely, without bitterness, for the first time, and it was a kind of happiness, at its heart the terror of an unclear recognition of the reality that set you free, touching you with as much foreboding as the sodden leaves falling in this day, or any cliche. (188)

Commenting on the repressive environment in which Young Mahoney lives, but can finally free himself of, Toolan points out:

This sterile, barren, violent world makes the children want to retaliate and forces them to exclude their father so that he has very little contact with them, and Young Mahoney has to survive on his own (42).

Certainly, Young Mahoney overcomes the tyrannical situation imposed on him by his father who likes his son to follow his father's footsteps and yield to the frustrating requirements of a highly dictatorial society. Throughout his way towards success and liberation, Young Mahoney has been decisive, ambitious and enthusiastic till he finally finds 
his own way. In this way, the protagonist of McGahern's The Dark can face all the challenges that hinder his way, and can finally achieve his goals and aspirations.

In this sense, young people can find in Young Mahoney a good example of the individual who is so determined that he can finally achieve success and lead a happy life.

The same spirit of challenge and determination characterizes The Leavetaking, a narrative in which McGahern tells us that Patrick Moran, the protagonist, is a young man who works as a teacher in a Dublin primary school. Moran and his colleagues in the school are faced with many obstacles and challenges which they try hard to overcome. These young men stir pity and sympathy. McGahern portrays them as struggling hard to find a way out of their repressive community. Malloy, a critic, describes these miserable young people referring to "O'Toole," one of Mahoney's colleagues," who "is rebuked for being a bachelor and for listening to cricket (an English and, therefore, foreign game) on the radio" (20); other two examples are Bo Hand and Tonroy, Malloy clarifies pointing out:

Bo Hand makes puerile gestures of defiance when he shows off holiday pictures of a beauty contest in the Isle of Man; Tonroy, once a friend of Patrick's, now holds him in contempt for what he had done. (20)

A careful reading of the novel shows that Moran, the central character of The Leavetaking, loves his mother, likes his work as a teacher despite the continuous interferences of his domineering father in his life and affairs. Moran's love for his mother is so powerful that he assures her to become a priest mainly to say Masses for her in her life and even after her death. When his mother dies, Moran has to move to lead his life in the barracks with the father. These memories come to Moran on the day when he has to leave his teaching position due to his marriage without the Church's permission. Such leavetakings from mother and work deepens the young man's sorrow but they at the same time gives him a strong motive for challenge and success.

Throughout the novel, McGahern makes us see and feel how Moran feels broken and isoloated as everything around him is being run in a mechanical way. The silly rules of the school frustrate not only the pupils but also the teachers who feel caged in a highly repressive environment. Describing this oppressive setting, Sampson--a critic-- tells us how the headmaster prowls like a "hound," a "cormorant scanning water," or "a gundog pointed towards sleeping game," enforcing his "complete authority" through fear (118).

As McGahern tells us in the book, the power of the priest and religion is very evident. Moran has to be accepted and approved by the Priest for his 
teaching position even though it is the headmaster who actually runs the process of hiring. "I can't appoint you'" the headmaster tells Moran, justifying his point of view as follows:

Father Curry is the Manager. He does the appointing: but in all the years he's never once gone against my recommendation, though of course the final say is his".

However, the disappointed young man has to leave Ireland and travel to London where he works as a bartender, and shortly after he meets Isobel, an American divorcee whom he loves strongly.

Insisting on marrying Moran, Isobel has a bitter confrontation with her father which results in her leaving him. More importantly, Isobel agrees to marry Moran in a registry's office. They return to Ireland so that Moran can resume his teaching duties. However Moran cannot reveal his marriage because it will mean the loss of his job since he married outside the church. "I explained how there were two salary scales for teachers in Ireland," Moran tells us in the narrative, adding:

One for women and single men, and a higher for married men. If I applied to go the higher scale they'd discover I wasn't properly married. If I remained on the single, which I'd have to do, they'd find out sooner or later in such a small city that I was living as a married man but not married. Either way I was certain to be fired. (142)

Unfortunately, the school authorities discover that Moran is married outside the church, and he must meet the principal. It is worth noting that Moran rejects to leave his job and insists that the manager priest who hired him fire him. "I won't resign, a mhaistir," he cries in a tone of anger and rejection:

"Why a mhaistir? You must know I've discussed this with Father Curry already. If you don't resign you'll be dismissed. Why bring it to that a mhaistir?" "I've thought about it too, a mhaistir, and I won't resign. If I was a bad teacher I'd resign, or had committed some crime, or had harmed a child it would be different. But I'm harming no one." (161)

It is important to know that Moran does not see his marriage to Isobel as a sin.

To defend his love, to stick to his principles, to free himself from the chains surrounding him and killing his dreams and ambitions, Moran challenges the priest, the headmaster, the domineering society, and all the forces that may stand against his love which he strongly defends and believes in. (Freyer 142). Thus, Moran has chosen to be fired from his job and to be 
freed from imprisonment in this "ugly coldness" for the higher value of that caring love. To quote Sampson,

This love is the antithesis of the exploitation... that is so markedly a part of the world of Patrick Moran's childhood. The novel is, then, on this realistic level, a drama of opposing notions of authority and authenticity and freedom...(119).

Thus, John McGahern's protagonist can finally face his challenges and find the freedom he has long sought. The moral lesson our young men can learn from McGahern's novels is that one's determination and belief in a certain principle can definitely give him/her power and courage to overcome all obstacles and achieve success. Accordingly, he /she can find some meaning in life.

\section{Acknowledgement:}

The authors would like to acknowledge financial support for this work from the Deanship of Scientific Research, Tabuk, Saudi Arabia. Grant No. 1436-0170.

\section{References:}

Freyer, Grattan. "Change Naturally: The Fiction of O'Flaherty, O'Faolain, McGahern." Eire-Ireland 18 (Spring 1893): 138-45.

Kennedy, Eileen. "The Novels of John McGahern: The Road Away

Becomes the Road Back." Contemporary Irish Writing. Eds. James D. Brophy and Raymond J. Porter. Boston: Iona College P, 1983. 115-126.

Malloy, Frank C. "The Novels of John McGahern." Critique 19.1 (1977): 527.

McGahern, John. The Dark. London: Faber \& Faber, 1965.

... The Leavetaking. London: Faber \& Faber, 1974.

Sampson, Denis. "A Note on John McGahern \& John McGahem's The

Leavetaking." Canadian Journal of Irish Studies 2.ii(1972): 61-65.

Toolan, Michael J. "John McGahern: The Historian and the

Pomographer." Canadian Journal of Irish Studies 7.2 (December 1981): 3955. 